\title{
INCREASING MATHEMATICS LEARNING INTERACTIONS USING COOPERATIVE LEARNING THINK PAIR SHARE ON STUDENTS OF CLASS VIII B IN SMP MUHAMMADIYAH 2 GAMPING YOGYAKARTA
}

\author{
Dwi Endarto ${ }^{a}$, Sumargiyani ${ }^{\mathrm{b}}$ \\ Program Studi Pendidikan Matematika FKIP UAD \\ Jalan Ring Road Selatan, Tamanan, Banguntapan, Bantul Yogyakarta \\ adwiendarto60@gmail.com, ${ }^{\mathrm{b}}$ sumargiyani04@yahoo.com
}

\begin{abstract}
This study was conducted because of the low interaction mathematics learning. The purpose of this study seeks to increasing interaction of mathematics learning in class VIII B of SMP Muhammadiyah 2 Gamping on second semester in academic year 2015/2016 using Model Cooperative Learning Think Pair Share. This research was classroom action research. The subjects were students of class VIII B of SMP Muhammadiyah 2 Gamping many as 30 students. The object of research is the application of Model Cooperative Learning Think Pair Share. Data collection techniques such as observation, interviews, and tests. Analysis of data using data analysis observation, analysis of interview data and test. This research is consisting of three cycles that include planning, action, observation and reflection. Research result showed that increased interaction study mathematics. Based on the observation of the data are the average percentage increase interaction mathematics learning in each cycle an average of $55 \%$ to the category of "enough" in Cycle I to 58.05\% with the category of "enough" in Cycle II became $79.17 \%$ with category of "strong" in Cycle III. The increase also occurred at an average of 65.34 cycles of the test results on the first cycle increased to 76.5 in Cycle II subsequently rose to 81.67 in Cycle III. And on mastery learning from $60 \%$ in the first cycle increased to $73.34 \%$ in Cycle II then increased again to $80 \%$ in Cycle III. Thus the results of the comparison between the results achieved with the targets set, has also shown that optimal results.
\end{abstract}

Keywords: Think Pair Share, interaction mathematics learning

\section{INTRODUCTION}

Education is one of the important aspects in human life. Because everything can come from education. And education is a very positive thing in this life. From education a nation has quality and existence and honor. The progress of a country can also be seen from the perspective of the need for education in it. One of the subjects in the school that is able to encourage student progress is Mathematics. Mathematics is an important subject in the school. Because besides being a basic science, mathematics is able to help in the development of other sciences. Because mathematics itself is an applied science whose application is so needed by science and technology. Mathematics in science that began to be studied from elementary school to high school. Even mathematics can still be learned at the college level.

Lerner in Abdurahman, Mulyono (2003: 252) argues that mathematics as a symbolic language is also a universal language that allows humans to think about, record, and communicate ideas about elements and quantities. Learning mathematics is a process of building or compiling an understanding of mathematics. Because the main focus of learning mathematics is to empower students to think about the mathematical knowledge that has been discovered by previous experts. Suherman, Erman et al (2003: 63). It becomes ironic, when most students assume that mathematics is a difficult lesson. Indicators of the difficulty of learning mathematics can be seen from the still low learning outcomes of mathematics, some students who still get math scores under the Minimum Completion Criteria (MCC).

When researchers make observations, it appears that the interaction there is still lacking so that researchers take the initiative to conduct research to improve learning interactions in mathematics. In this study the researchers tried to apply the cooperative learning type Think-Pair Share (TPS) model, a learning strategy that was first developed in 1981, by Frang Lyman and colleagues. According to Trianto 
(2009: 67) there are four approaches that should be part of a collection of teacher strategies in applying part of the teacher's strategy collection in applying cooperative learning models, namely STAD, JIGSAW, TGT and structural approaches including NHT and TPS.

The benefits of the TPS type cooperative learning model are allows students to work together with others, optimize student participation, and provide opportunities for students to show their participation in other students (Huda, Miftahul 2014: 206). For some reason, researchers tried to apply the TPS type cooperative learning model. This learning begins with the teacher asking questions or issues related to the lesson for students to think about. After that the teacher gives them the opportunity to think about the answers (Suprijono, Agus. 2013: 91).

Therefore, in this study the authors are interested in conducting research about Efforts to Improve Learning Mathematics Interaction Using Cooperative Learning Models of Think Pair Share Type in Class VIII B Even Semester of SMP Muhammadiyah 2 Gamping in the Academic Year of 2015/2016. As stated in the background above, the problems formulated in this study are whether using the TPS type cooperative learning model can improve the mathematics learning interaction of class VIII B even semester of SMP Muhammadiyah 2 Gamping in the academic year of 2015/2016?. In accordance with the elaboration of the problem formulation, it can be stated that the purpose of this study is to increase mathematics learning interactions using the TPS type cooperative learning model in class VIII B even semester of SMP Muhammadiyah 2 Gamping in the academic year of 2015/2016.

\section{METHODS}

This study included the type of Classroom Action Research (CAR), which is an examination of learning activities in the form of an action, which is deliberately raised and occurs in a class together (Arikunto, Suharsimi, 2007: 3). This research was conducted at SMP Muhammadiyah 2 Gamping, carried out by adjusting the mathematics lessons in the class. The research was conducted in the even semester of the academic year of 2015/2016. The subjects in this study were all students of class VIII B in the even semester of SMP Muhammadiyah 2 Gamping in the academic year of 2015/2016. The object in this study is the increasing interaction of learning mathematics using cooperative learning models of the TPS. The research procedure used in this classroom action research consists of three cycles, each of which consists of four stages. In detail the procedure for class action research for each cycle is described as follows.

1. Preparation

Before conducting the research, the researcher prepares, among others: Visiting the school to ask permission to do the research. Then conduct an interview with the mathematics subject teacher at the school.

2. Cycle I

\section{a. Planning}

At this stage the researcher designs the actions to be carried out in the research, namely: The researcher prepares the lesson Plan according to the subject of the Circle. The material in Cycle I is to explain the elements of the circle, in Cycle II calculate the circumference and area of the circle and in Cycle III explain the relationship of the center angle, arc length, area of sector and use it in problem solving. Then the researcher compiled and prepared observation sheets, interview guidelines and cycle test questions.

b. Implementation

At this stage the researcher carries out learning with the TPS type cooperative learning model that has been designed based on the prepared lesson plan. In the initial activity, the researcher opens learning and asks about students' initial knowledge about the Circle. Then in the core activity, the researcher presents Circle material, the researcher gives an issue related to the material, then the students think of the answer. After that the researcher divides students into 6 groups and directs to discuss and work together with each group to solve problems. Then the researcher invited students to convey ideas and results of group discussions. In the closing activity, the researcher gave the question as a repetition of the material then the researcher made a conclusion with the students. 


\section{c. Observation}

Activities at this stage are carried out by researchers and observers during the learning process, namely by using the observation sheet that has been made. Observations were made to find out things that happened during learning and the obstacles faced during the learning process took place. In this phase the research observed was student learning interactions in mathematics learning as well as obstacles encountered during the implementation of the action

d. Reflection

Reflections were carried out by observers and researchers by analyzing the observations of student learning interactions on observations. Reflections are carried out in the form of discussions to discuss and evaluate the implementation of actions. Analysis was carried out to measure the advantages and disadvantages contained in Cycle I and then discuss the results of the collaboration analysis for improvement in the implementation of Cycle II and Cycle III. While for Cycle III the stages are almost the same as the stages in Cycle I and Cycle II.

Data collection techniques in the form of observation, interviews, and tests. The research instrument is a tool used in data collection, including: Guidelines for interviews, observation sheets, test questions. Data from student interaction observation results were analyzed using a percentage formula, namely:

$$
P=\frac{n m}{N} \times 100 \%
$$

Information :

$\mathrm{P} \quad$ : student interaction scores.

$\mathrm{Nm} \quad$ : number of scores obtained.

$\mathrm{N} \quad$ : maximum indicator score

(Nur Shoimah, Alfi, 2015:41)

Table 1. Qualification of Student Interaction Sheet Score Results

\begin{tabular}{|c|c|c|}
\hline No & Percentage & Qualification \\
\hline 1 & $80 \%<\mathrm{P} \leq 100 \%$ & Very well \\
\hline 2 & $60 \%<\mathrm{P} \leq 81 \%$ & Well \\
\hline 3 & $40 \%<\mathrm{P} \leq 61 \%$ & Enough \\
\hline 4 & $20 \%<\mathrm{P} \leq 41 \%$ & Less \\
\hline 5 & $0 \% \leq \mathrm{P} \leq 21 \%$ & Less once \\
\hline
\end{tabular}

(Riduwan, $2013: 41$ )

Analysis of student learning outcomes data refers to $\mathrm{MCC}$ in predetermined mathematics subjects. To calculate the class average value used the formula:

$$
\bar{x}=\frac{\sum x_{i}}{N}
$$

Keterangan:

$\bar{x} \quad$ : class average value

$x_{i} \quad$ : value obtained by students

$N \quad$ : the number of students in one class

To calculate the percentage of mastery learning the formula is used:

$$
P=\frac{F}{N} \times 100 \%
$$


Information:

P : Percentage of mastery learning

$F \quad$ : Number of students completed

$N \quad$ : total number of students

In accordance with the characteristics of classroom action research, the success of the study is marked by changes in the direction of improvement, both related to the implementation of learning and learning outcomes. In this study to determine the success of the action is characterized by an increase in the percentage of student learning interactions greater than $60 \%$ with good criteria.

\section{RESULTS AND DISCUSSION}

This classroom action research aims to improve the mathematics learning interaction of class VIII B of SMP Muhammadiyah 2 Gamping Yogyakarta by using the TPS ytype of cooperative learning model. The study was conducted in three cycles, one meeting in Cycle I and two meetings in Cycle II and III. In the implementation of the cycle III action has increased students' mathematics learning interactions. The following is a table of comparison of the achievement of students' mathematical learning interaction skills with the TPS cooperative learning model in Cycle I, Cycle II and Cycle III.

Table 2. Increased Observation Results of Mathematics Learning Interactions of Students in Cycle I, Cycle II and Cycle III

\begin{tabular}{|c|c|c|c|c|}
\hline No & Indicator & Cycle I & Cycle II & Cycle III \\
\hline 1 & $\begin{array}{l}\text { Interaction } \\
\text { between } \\
\text { friends }\end{array}$ & $50,83 \%$ & $54,16 \%$ & $80 \%$ \\
\hline 2 & $\begin{array}{l}\text { Student and } \\
\text { teacher } \\
\text { interaction }\end{array}$ & $57,5 \%$ & $60 \%$ & $75,83 \%$ \\
\hline 3 & $\begin{array}{l}\text { Student } \\
\text { interaction } \\
\text { with learning } \\
\text { resources }\end{array}$ & $56,67 \%$ & $60 \%$ & $81,67 \%$ \\
\hline 4 & $\begin{array}{l}\text { Average } \\
\text { mathematics } \\
\text { learning } \\
\text { interactions }\end{array}$ & $55 \%$ & $58,05 \%$ & $79,17 \%$ \\
\hline
\end{tabular}

Table 3. Increased Learning Outcomes of Cycle I, II and III Tests 


\begin{tabular}{|l|c|c|c|}
\hline \multirow{2}{*}{ Evaluation Result } & \multicolumn{3}{|c|}{ Activities } \\
\cline { 2 - 4 } & Cycle I & Cycle II & Cycle III \\
\hline The highest score & 90 & 95 & 90 \\
\hline Lowest value & 40 & 45 & 55 \\
\hline Average value & 65,34 & 76,5 & 81,67 \\
\hline $\begin{array}{l}\text { Many students } \\
\text { complete }\end{array}$ & 18 & 22 & 24 \\
\hline $\begin{array}{l}\text { Many students are } \\
\text { not finished }\end{array}$ & 12 & 8 & 6 \\
\hline Mastery learning & $60 \%$ & $73,34 \%$ & $80 \%$ \\
\hline
\end{tabular}

Table 4. Result of cycle test

In Cycle I, Cycle II and Cycle III mathematics learning was carried out using the TPS of cooperative learning model. From Table 3 which is the result of observation, it shows an increase in students' mathematical learning interactions in each cycle. On average students have interacted well because students have been able to ask the teacher, answer the teacher's questions when learning takes place. Students have also been seen wanting to ask friends, answer friends' questions and participate actively in their groups, and be able to use learning resources to find information about questions and as a way to solve questions. This can be seen in Cycle I the percentage of interaction between friends of $50.83 \%$ increased to $54.16 \%$ in Cycle II and increased again to $80 \%$ in Cycle III. The percentage of student and teacher interactions also increases. This can be seen in Cycle I the percentage of student and teacher interaction of $57.50 \%$ increased to $60 \%$ in Cycle II and increased again to $75.83 \%$ in Cycle III. The percentage of student interactions with learning resources also increases. This can be seen in Cycle I the percentage of student interaction with learning resources of $56.67 \%$ increased to $60 \%$ in Cycle II and increased again to $81.67 \%$ in Cycle III.

From Table 4 which is the result of a cycle test. Based on cycle tests there was an increase as well, on the average cycle test results of 65.34 in Cycle I increased to 76.5 in Cycle II and increased again to 81.67 in Cycle III. And the learning completeness seems to increase from $60 \%$ in Cycle I increased to $73.34 \%$ in Cycle II and increased again to $80 \%$ in Cycle III.

From the overall data above, the research objectives were achieved in Cycle III so that the research was considered completed and the results showed an increase in mathematical learning interactions using TPS type of cooperative learning models of class VIII B even semester of SMP Muhammadiyah 2 Gamping in the academic year of 2015/2016. Thus the action hypothesis is proven to be accepted.

\section{CONCLUSION}

Based on the results of the research carried out on class VIII B even semester at SMP Muhammadiyah 2 Gamping in the academic year of 2015/2016 on the subject of the circle can be concluded that by using the cooperative learning model Think Pair Share (TPS) can improve students' mathematics learning interactions. This can be proven from:

1. The percentage of students' mathematics learning interactions increases in each cycle. From the first cycle the average percentage of observations of mathematics learning interactions was $55 \%$ students. In Cycle II it increased to 58.05\%. And in Cycle III it increased to $79.17 \%$ reaching good criteria.

2. The increase also occurred on the average cycle test results of 65.34 in Cycle I increased to 76.5 in Cycle II and increased again to 81.67 in Cycle III. The increase also occurred in learning completeness from $60 \%$ in Cycle I increased to $73.34 \%$ in Cycle II and increased again to $80 \%$ in Cycle III. 


\section{REFERENCES}

Abdurrahman, Mulyono. 2003. Psikologi Bagi Anak Berkesulitan Belajar. Jakarta: Rineka Cipta.

Arikunto, Suharsimi. 2007. Penelitian Tindakan Kelas. Jakarta: Bumi Aksara.

Huda, Miftahul. 2014. Model-model Pengajaran dan Pembelajaran. Yogyakarta: Pustaka Pelajar.

Nur Shoimah, Alfi. 2015. Upaya Meningkatkan Interaksi Belajar Matematika Menggunakan Metode Pembelajaran Aktif Tipe Index Card Match Pada Siswa Kelas VIII Semester Genap SMP Muhammadiyah Piyungan Kabupaten Bantul Tahun Ajaran 2014/2015. Skripsi. Yogyakarta: Universitas Ahmad Dahlan.

Riduwan. 2013. Dasar-dasar Statistika. Bandung: Alfabeta.

Suherman, Erman. 2003. Strategi Pembelajaran Matematika Kontemporer. Bandung: Universitas Pendidikan Indonesia.

Suprijono, Agus. 2013. Cooperative Learning Teori dan Aplikasi Paikem. Yogyakarta: Pustaka Pelajar.

Trianto. 2009. Mendesain Model Pembelajaran Inovatif Progresif Konsep, Landasan, dan Implementasinya pada Kurikulum Tingkat Satuan Pendidikan. Jakarta: Kencana. 